\title{
تثبيط التغيرات الخلوية الوراثية المستحثة بعقار MMC في الفأر الأبيض باستخدام Urtica pilulifera مستخلصي نبات القريص نوع الانعال
}

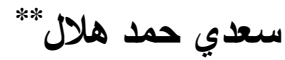

مركز الاشعاع الحياتي/وزارة العلوم و التكنولوجيا/ بغداد/ العراق. * جامعة القادسية/ كلية التربية/ السماوة/ العراق.

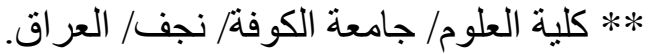

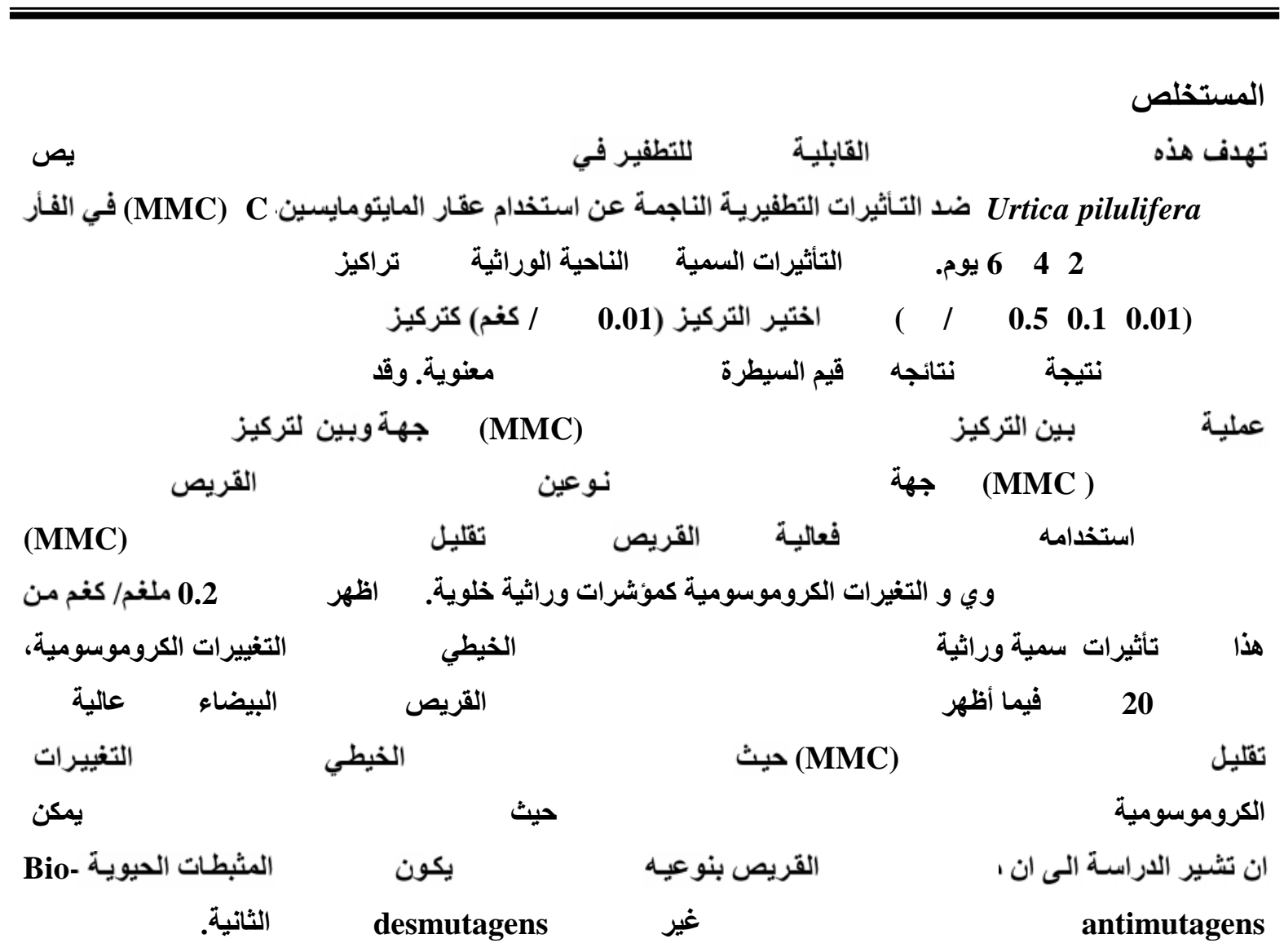

\section{Abstract}

The aim of this study was to investigate the potency of aquatic $\&$ alcoholic extracts of the leaves of Urtica pilulifera plant against mutagenecity of Mitomycine C (MMC) drug in mice. 
The genotoxic effects of three different concentrations $0.01,0.1 \& 0.5 \mathrm{mg} / \mathrm{kg}$ from aqueous or ethanolic extract were tested in mice. $0.01 \mathrm{mg} / \mathrm{kg} \mathrm{bw}$ from either types of extracts were selected as non-genotoxic in comparison to control. Drug-plant extract interaction was tested using mitotic index \& Chromosomal aberrations as bioindicators for detection of the potency of the plant extract in reduction of MMC-induction of cytogenetic effects. Two types of treatments were followed, either plant extracts were given before $(2,4,6)$ days, or after $(2,4,6)$ days, of treatment with MMC. The results revealed that $0.2 \mathrm{mg} / \mathrm{kg}$ of MMC significantly inhibited bone marrow cell division and increased the spontaneous levels of chromosomal aberration up to 20 times. Treatment of mice with aqueous or alcoholoic leaf-extract reduced significantly $(p<0.01)$ the genotoxic effects of MMC. This reduction was more pronounced in animals which were given the extract after treatment with MMC comparing to its treatment before the MMC exposure. These results indicated that Utrtica pilulifera leaves extract behave as bio-anti mutagen first degree and acting indirectly in the $2^{\text {nd }}$ degree.

$$
\begin{aligned}
& \text { هذا }
\end{aligned}
$$

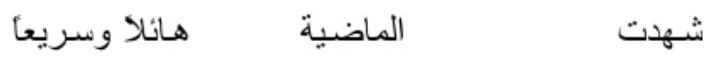

$$
\begin{aligned}
& \text { Glycyrrhiza Glubar } \\
& \text { تثبيط يرات الكروموسومية } \\
& \text { التبـادل الكروماتيـدي الناجمـة عـن تـأثير عقدير }
\end{aligned}
$$

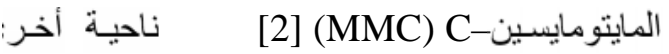

$$
\begin{aligned}
& \text { T. kotochyonus } \\
& \text { ظهرت } \\
& \text { M. longifolia } \\
& \text { التغيرات الكروموسومية الناجمـة تأثثر } \\
& \text { السايكلوفوسفامايد Cychlophosphamid [3] } \\
& \text { القريص Urtica Pilulifera ينتمي } \\
& \text { النباتية Urticaceae } \\
& \text { المنطقتين الثمالية }
\end{aligned}
$$

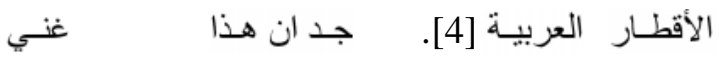

$$
\begin{aligned}
& \text { بالفيتامينات } 300 \text { جزءء/ مليون، } 380 \text { C / مليون، } \\
& \text { / } 1500 \text { A }
\end{aligned}
$$

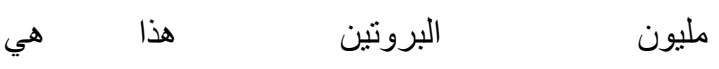

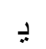

$$
\begin{aligned}
& \text { الإحصـائيات البيئية } \\
& \% 90
\end{aligned}
$$

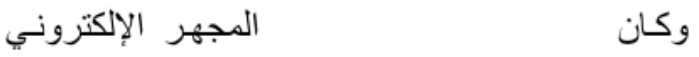

$$
\begin{aligned}
& \text { واكتثـاف المـادة الوراثية وأثرهـا والطفرة الوراثية } \\
& \text { الكروموسومية ودور هـا ظهور } \\
& \text { توجه }
\end{aligned}
$$

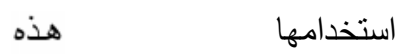

$$
\begin{aligned}
& \text { لها. تلعب النباتات دور أ مهمـا في وقاية } \\
& \text { الخليـة مـن عمليـات التسـرطن، مـن خـلال حمايـة الجزيئة } \\
& \text { الهـف فـي الخليـة (DNA) التبّبط المسـرطن او تحفيز } \\
& \text { جهاز ا لـلاح جزيئة الـ DNA، او ايقاف انقسام الخلايـ } \\
& \text { السرطانية، او من خلال زيادة في طرح و تثبيط التنثيط } \\
& \text { الطبيعية المهمة } \\
& \text { للمسرطن داخل الخلية . } \\
& \text { الطبية. ومن } \\
& \text { مثل هذه هو }
\end{aligned}
$$




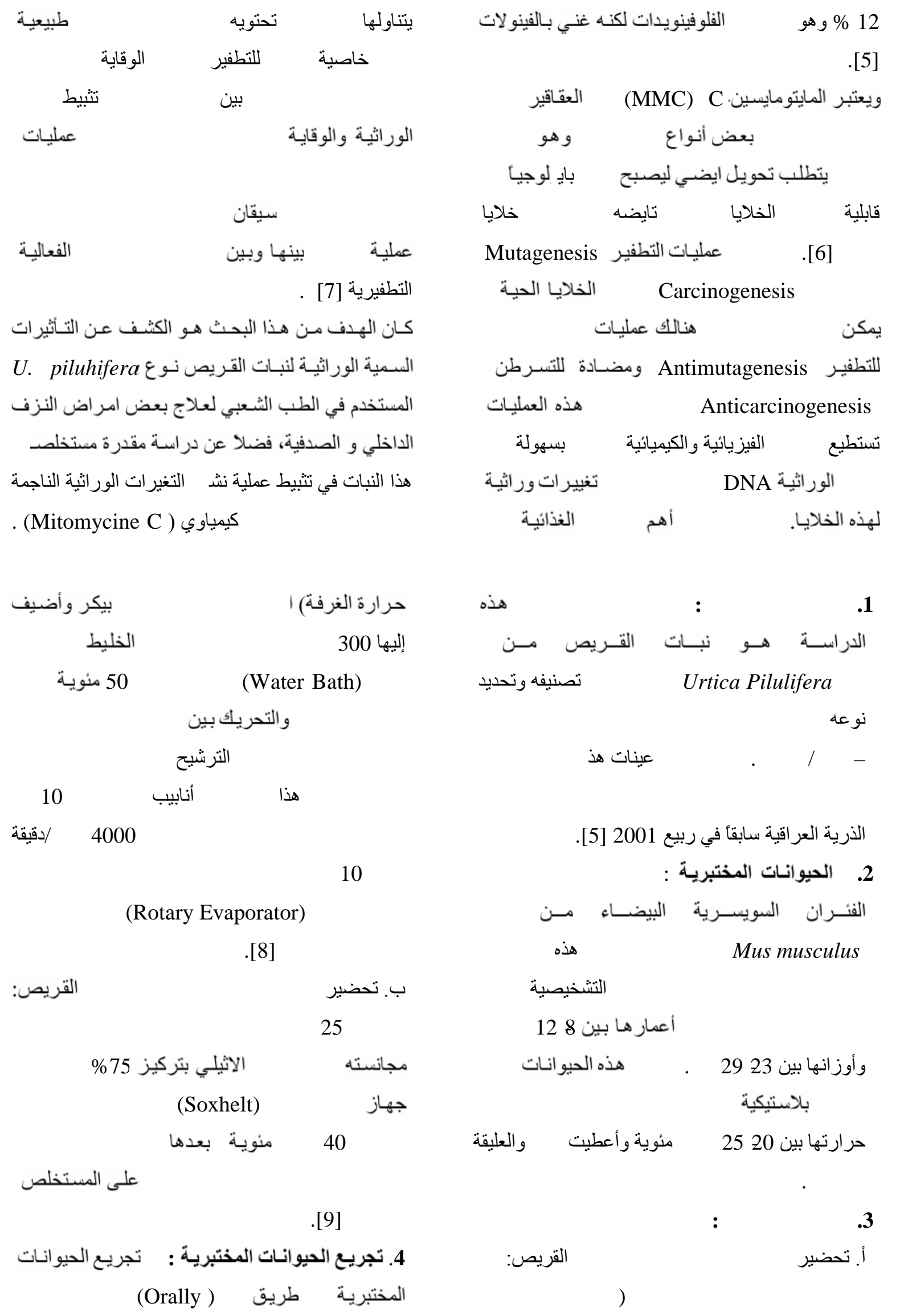


27 مyئة Hypotonic Solution

$$
\text { الأنابيب } 37 \text { مئوية } 30
$$

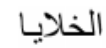

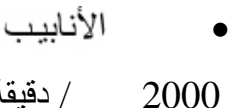

$$
2000
$$

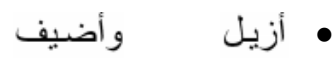

Fixative Solution

الميثانول مـع حجم حامض الخليك الثلجي) .

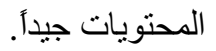

$$
4
$$$$
\text { الأنابيب }
$$

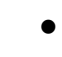

$$
\text { عملية التثبيت } 1 \text { اجية نظيفة }
$$

20 دقيقة

$$
\begin{aligned}
& \text { غسلها } \\
& \text { التالية: } \\
& \text { الخيطي: } \\
& \text { تكبير } 600 \\
& 1000 \text { خلية وغير }
\end{aligned}
$$

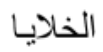

$$
\begin{aligned}
& \text { المئويـة } \\
& \text { للمعادلــــــة: }
\end{aligned}
$$

$$
\text { تجريع }
$$

خصيصأ لهذا نهاية غير

$$
\text { 5. ختبارات الوراثية: طريقة الحصول على الخلايـا }
$$$$
\text { الوراثية الطريقة التالية [10] : }
$$

$$
\text { الكولجسين }
$$$$
\text { • }
$$

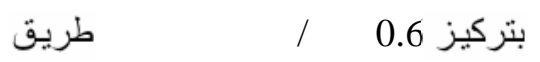

.(Intraperitonially)

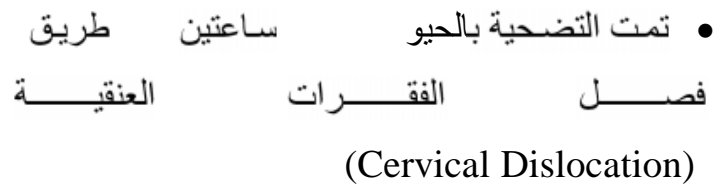

التشريح

جهنه الظهرية

الجهة البطنيـة للحيوان

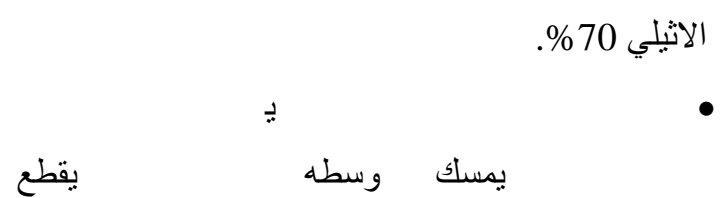

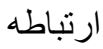

$$
\text { فوهة }
$$

(Phosphate

5

(Buffer Saline (PBS)

$$
\text { بحيث يصبح لونه ابيض فار غ من الخلايا. }
$$

$$
\text { الأنابيب الحاوية }
$$

$10 \quad$ 2000)

(Centrifuge)

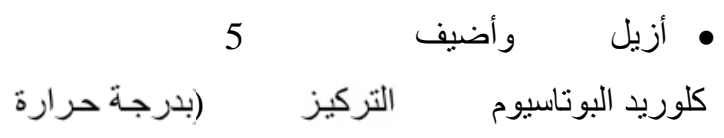

= = = = = = = = = 


$$
\text { مجاميع ثانوية : }
$$

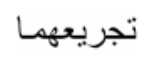

الثانوية

حقنهما

يومين

بالتركيز

6

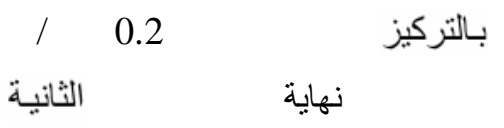

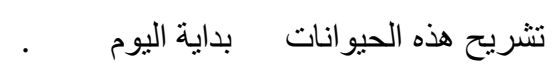

$$
\text { الثانوية الثانية : بلثية }
$$

$$
\text { بالتركيز }
$$$$
\text { بداية اليوم }
$$$$
\text { : : الثانويسة }
$$

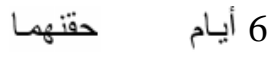

6

بالتركيز

نهايـة

بالتركيز

الجرعة السادسة للمستخلص وتم تثريح

الحيوانات بداية اليوم

$$
\text { السيطرة }
$$

أيضا

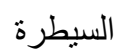

MMC

حقنهما

الرئيسية لثنانية فهي أيضـأ 10

وهي أيضـا

تجريعها

مجموعتين وبه

الرئيسية الثانيـة (التجريع

36

$$
\text { ) هيئ لهذه }
$$

16

$$
\text { مجمو عتين ئيسبنين }
$$

يتم حقنها جميعاً

اليوم نفسه الكيميائي MMC و هي بدور ها

$$
\text { تجريعها بالتركيز }
$$

6

وهي

$$
\text { الور اثية }
$$

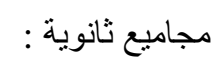

\section{تجريعهما}

$$
\text { : : }
$$

6

الزيتية

$$
\begin{aligned}
& \text { حيث } \\
& \text { الخيطي }
\end{aligned}
$$

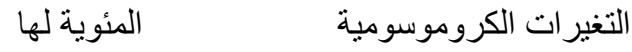

$$
\begin{aligned}
& \text { السيطرة الموجبة و السالبة: }
\end{aligned}
$$

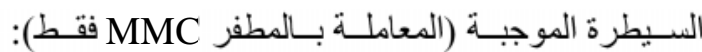

$$
\begin{aligned}
& \text { ضمت السيطرة } \\
& 642 \\
& \text { MMC } \\
& \text { وهذه } \\
& \text { السيطرة فأنها } \\
& 24
\end{aligned}
$$

جانب السبطرة السالبة التي ضمت فأرين حقنت بالدارى

و شرحت مع حيوانات السيطرة الموجبة.

6. دراسـة التـأثيرات الوراثيـة للمستخلص المـائي و

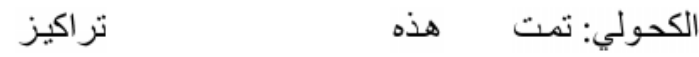

القريص

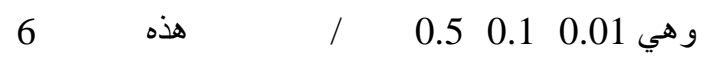
تجريع فأرين

ولمدة 6 أيسام وبعدها

$$
\text { الوراثية عليهـا }
$$

الخيطي Mitotic index

التغييرات الكروموسـومية (CA)Chromosomal التركيز

Aberration

0.01 ملغم/ كغم كتركيز أمثل للمستخلص المسائي

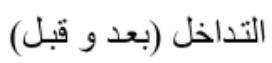

\section{. MMC}

بين

7.

$$
\text { الكيمياوي MMC }
$$

$$
\begin{aligned}
& \text { الأولى (التجريع } \\
& 20 \\
& \text { ) : هيئ لهذه } \\
& 10 \\
& \text { مجمو عتين رئيسيتين } \\
& \text { للأوراق وتضـم هذه } \\
& \text { تجريعها بالمست } \\
& \text { تجريعها بالتركيز } \\
& \text { المجموعـة } 6 \text { فئر ان }
\end{aligned}
$$

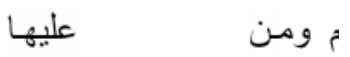




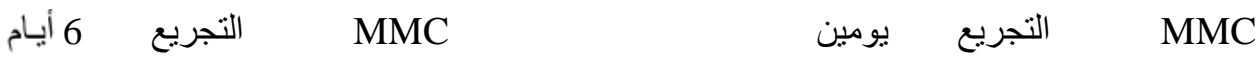

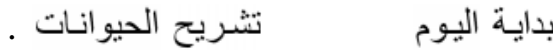

$$
\begin{aligned}
& \text { الرئيسية الثانية فهي أيضا } 16 \\
& \text { حقنها جميعها } \\
& \text { هو } \\
& \text { MMC } \\
& \text { الرئيسية }
\end{aligned}
$$

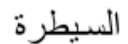

$$
\begin{aligned}
& \text { يجري عليها }
\end{aligned}
$$

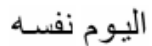

$$
\begin{aligned}
& \text { تشريح الحيوانات. } \\
& \text { بداية اليوم } \\
& \text { تجريعهما } \\
& \text { الثنانوية الثانية : }
\end{aligned}
$$

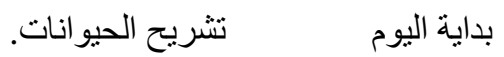

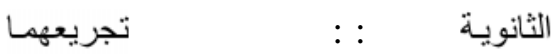

$$
\begin{aligned}
& 6 \\
& \text { بالتركيز }
\end{aligned}
$$

\section{التحليل}

إيجاد

(LSD)

$$
\text { S.P.S.S }
$$

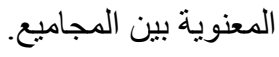

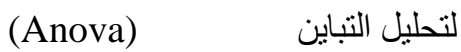

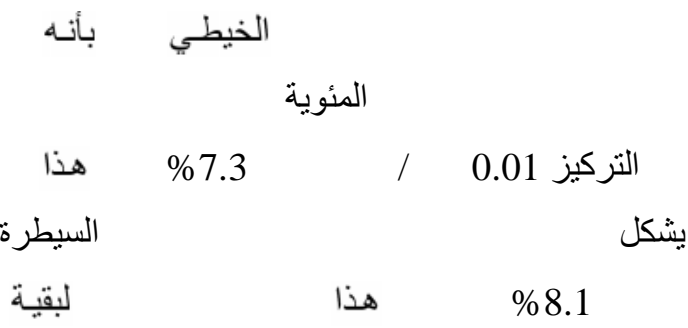

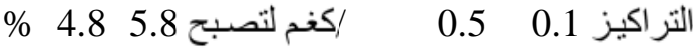

التوالي وبمستوى معنوي عـالي ( > 0.001) بعينة السيطرة السـالبة. أمـا فيمـا يخص ليص

التغير ات الكروموسومية التي كانت اغليتهـا نوع كسر

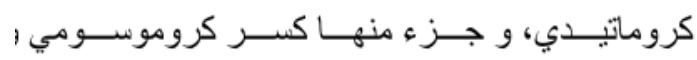
كروموسوم حلقي. نسبة العدد الكلي لهذه التغيرات / بزين 0.10 .5

لتصبح 3.33 .2 \% على التوالي

$$
(0.05>)
$$

$$
\text { ) }
$$$$
\text { بين }
$$

الكيمياوي MMC<smiles>[AlH2][AlH2]</smiles>

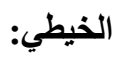

$$
\text { المئوية }
$$

( )

الخيطي

المئويـة

MMC :
1. التأثيرات الوراثية للعقار MMC: MMC

في معدلات معامـل الانقــام الخيطي لخلايـا نقي العظم

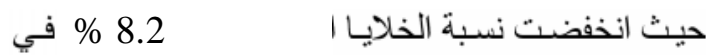
السيطرة السالبة الى 1.7 \% 246 كما ان المعاملة بهذا العقار ادت الى استحثاث التغيرات الكروموسـومية الـي شـوهدت مثنل : كسـر كروماتيـدي، كسر كروموسـومي و كروموسوم حلقي في خلايـا نقي

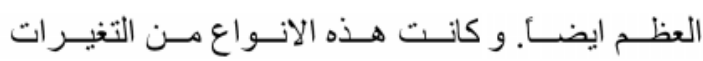
الكروموسومية تثناسب طرديأ مع فترة المعاملة 6 ساعات من المعاملة بـالمطفر الكيمياوي MMC حيث تثــير الدراسـات السـابقة [10] السى انخفـاض مسـتوى تركيز هذا العقار في جسم الفأر يظهر بعد 6 سـاعات، علمأ ان اعلى مستوى يصله في مصل دم الفأر هو بعد 3 ساعات من المعاملةة و يبدأ بالانخفاض تدريجيأ من خلال طرحه في الادرار الى ان يصل المستوى غير المحسوس

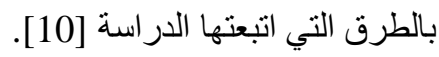
2. التأثيرات الوراثية 


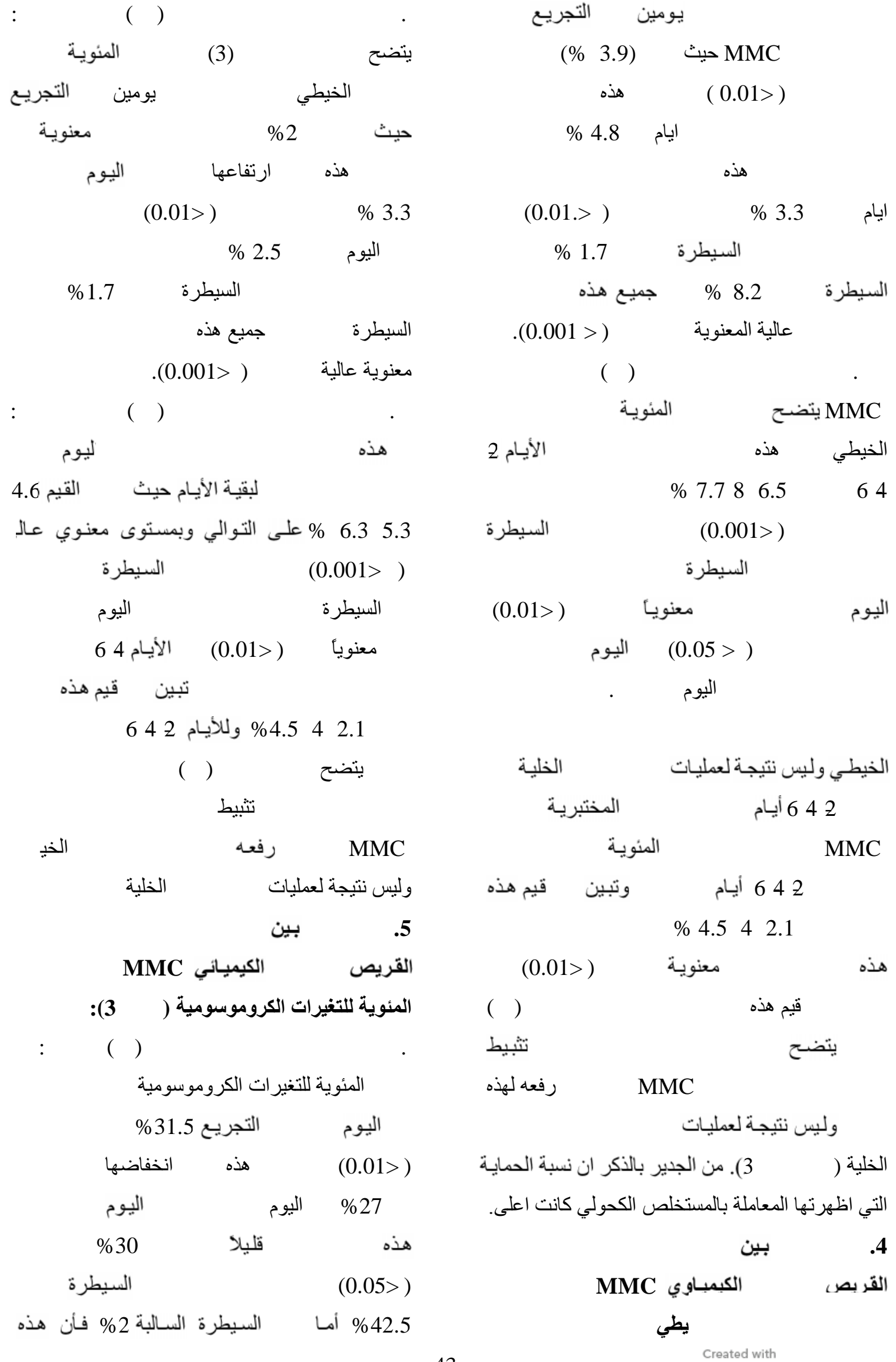




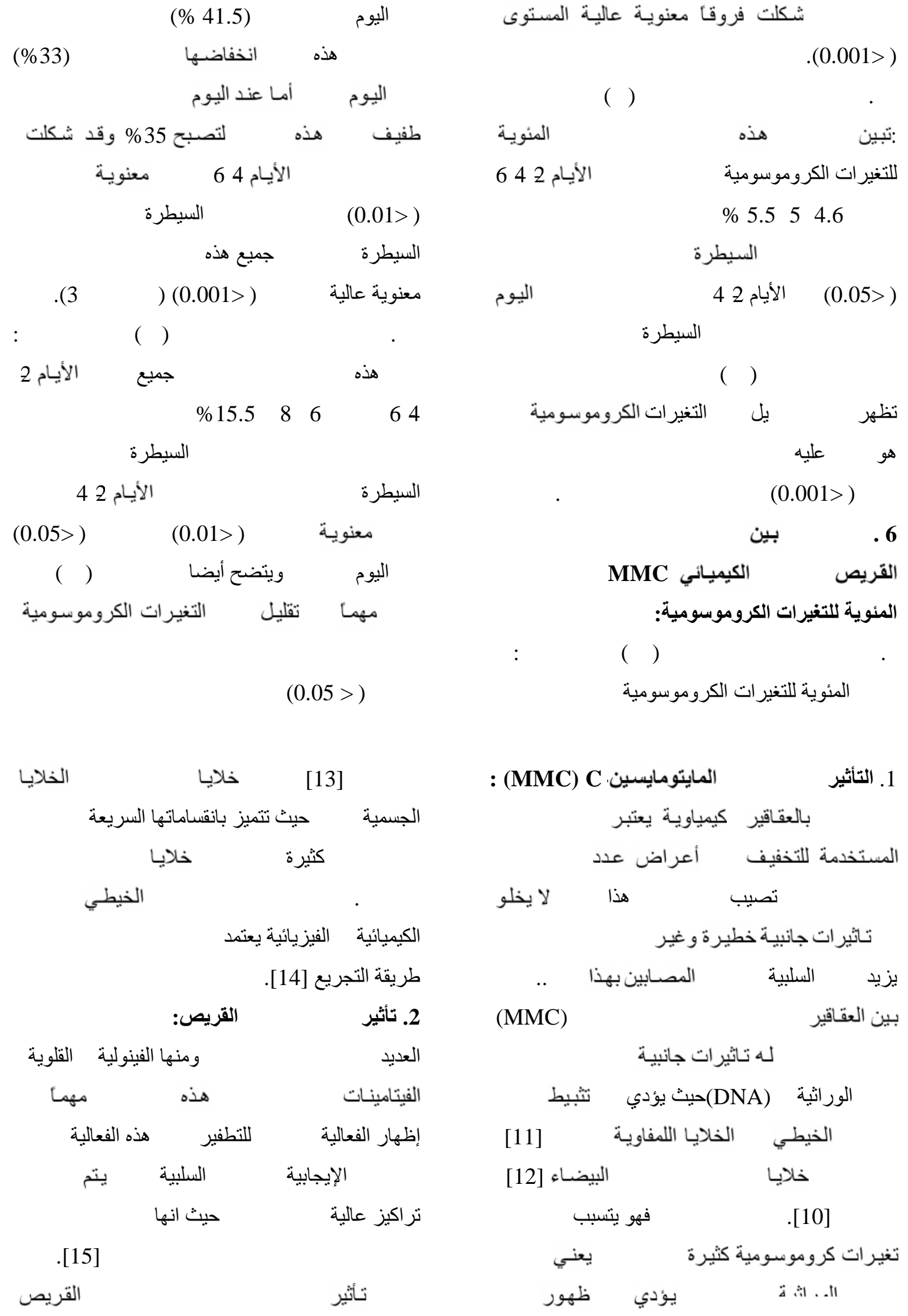




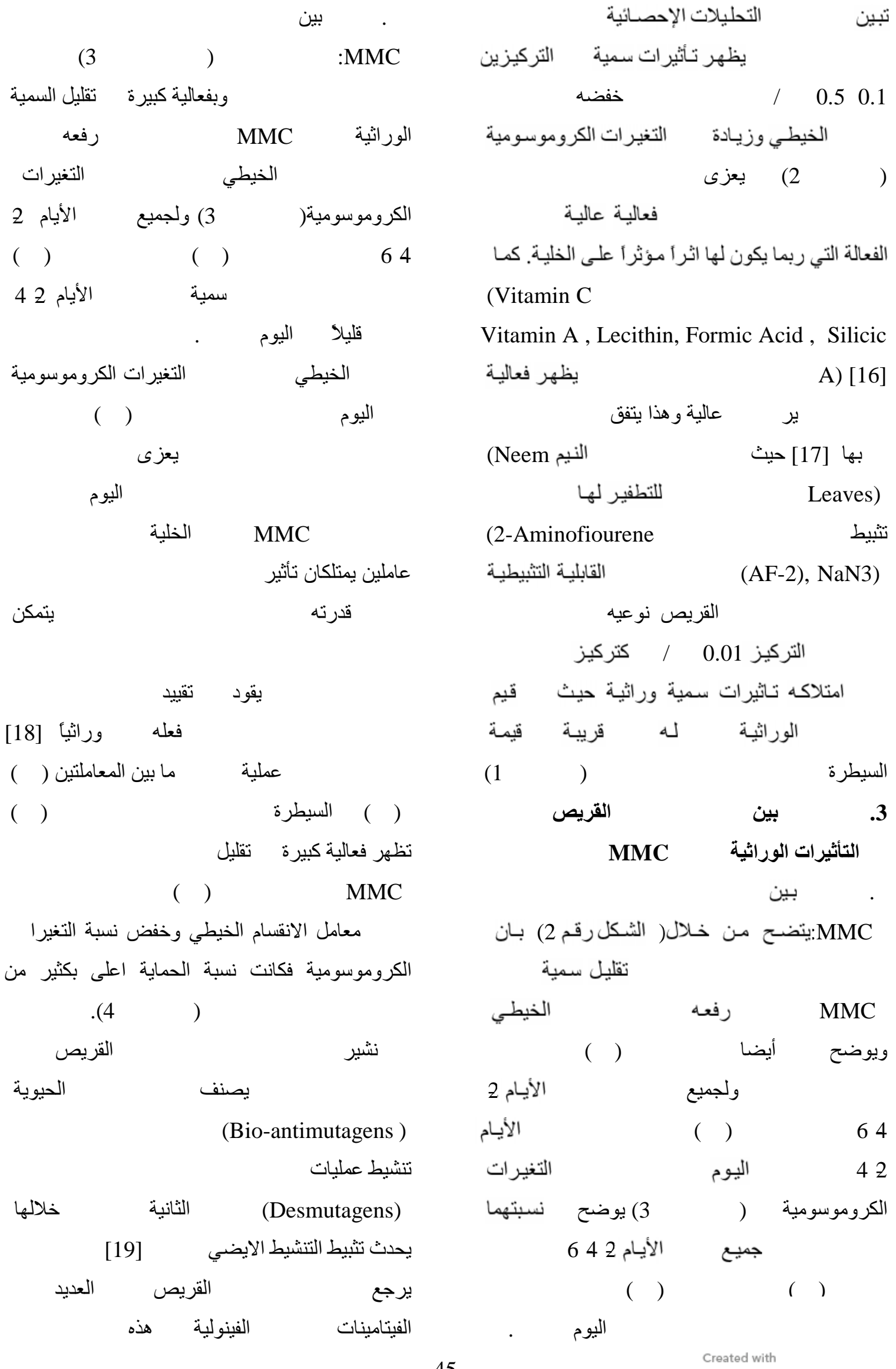




\begin{tabular}{|c|c|c|c|c|c|}
\hline Escherichio حيث & oli K12 & 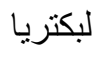 & رهما و هذا يتفق & لور اثية وتقليل دو & تنبيط \\
\hline & هذا & & الريحان & & إليه [15] \\
\hline 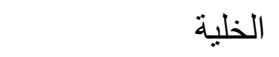 & DNA & & الحيوي & للتطفير & يمتلك فعالية \\
\hline & & & (Spontaneus & $\begin{array}{l}\text { Mutation ) } \\
\text { (Induced mu }\end{array}$ & لذاتية \\
\hline
\end{tabular}

(1): أستحثاث التغيرات الكروموسومية في خلايا نخاع عظم الفأر المختبري بعد معاملتها بالمطفر الكيمياوي

MMC

\begin{tabular}{|c|c|c|c|c|c|}
\hline \multirow{2}{*}{ مجموع التغيرات } & \multicolumn{3}{|c|}{ التغيرات الكروموسومية } & & \\
\hline & & & كسر كروماتيدي & & \\
\hline & 0.00 & 0.8 & 1.2 & 8.1 & السيطرة \\
\hline & & & & & \\
\hline 41.5 & 5.3 & 13.5 & 22.7 & 2.1 & اليوم الثاني \\
\hline 33.0 & 4.3 & 10.5 & 18.2 & 4.0 & اليوم الر ابع \\
\hline 29.0 & 5.0 & 9.5 & 14.5 & 4.5 & اليوم السادس \\
\hline
\end{tabular}

(2): تاثير مستخلصي نبات القريص على الانقسام الخلوي والتغيرات الكروموسومية خلايا نخاع

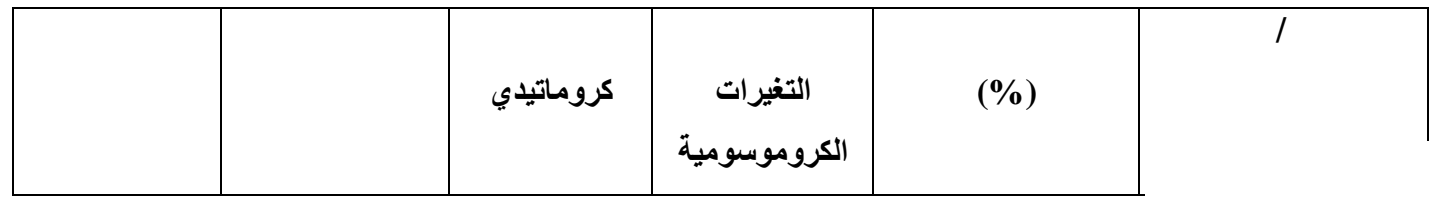




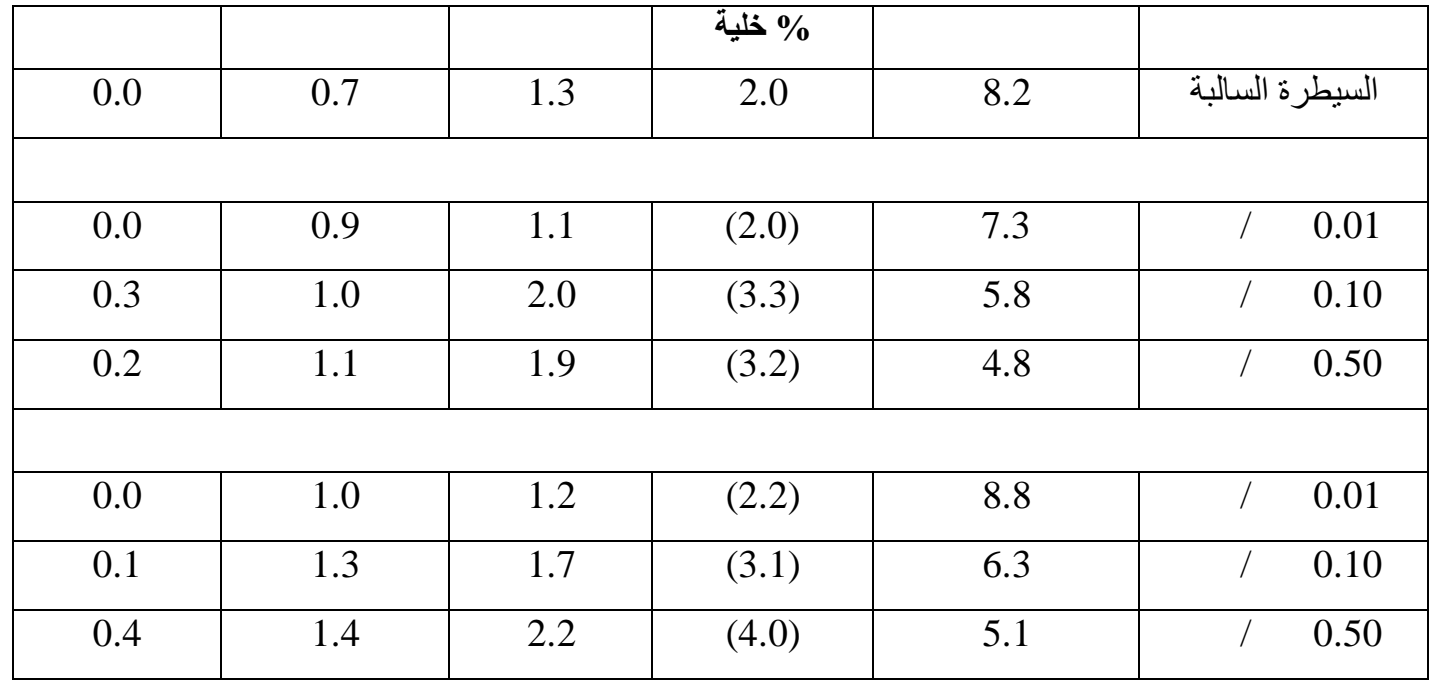

(3): القابلية التثبيةية لمستخلص نبات القريص على التاثيرات الخلوية الوراثية المستحثة بعقار MMC

خلايا

\begin{tabular}{|c|c|c|c|c|c|}
\hline الكروموسومية في 100 خلية التغيرات & & & كروماتيدي & & \\
\hline$(2.0)$ & 0.0 & 0.7 & 1.3 & 8.2 & السيطرة السالبة \\
\hline$(42.5)$ & 8.5 & 14.2 & 19.8 & 1.7 & $\begin{array}{c}\text { السيطرة الموجبة } \\
\text { MMC } \\
\text { / } 0.2\end{array}$ \\
\hline (41.5) & 7.8 & 14.5 & 18.0 & 2.0 & 2 يوم \\
\hline$(33.0)$ & 5.3 & 11.9 & 15.5 & 3.3 & 4 يوم \\
\hline$(35.0)$ & 6.7 & 12.8 & 15.7 & 2.5 & 6 يوم \\
\hline & & & & & \\
\hline$(15.5)$ & 1.0 & 8.0 & 6.5 & 4.6 & 2 يوم \\
\hline$(8.0)$ & 0.0 & 3.0 & 5.0 & 5.3 & 4 يوم \\
\hline$(6.0)$ & 0.0 & 2.2 & 4.8 & 6.3 & 6 يوم \\
\hline$(31.5)$ & 3.5 & 11.3 & 16.7 & 3.9 & 2 يوم \\
\hline$(27.0)$ & 3.7 & 9.4 & 13.9 & 4.8 & 4 يوم \\
\hline$(30.0)$ & 4.7 & 10.5 & 14.8 & 3.3 & 6 يوم \\
\hline
\end{tabular}




\begin{tabular}{|l|l|l|l|l|l|}
\hline$(4.6)$ & 0.0 & 0.5 & 3.1 & 6.5 & 4 يو يو 4 \\
\hline$(5.0)$ & 0.0 & 0.4 & 4.6 & 7.7 & 8.7 \\
\hline$(5.5)$ & 0.0 & 0.6 & 4.9 & 8.7 \\
\hline
\end{tabular}

(4): اثر التذاخل بين المستخلصين المائي و الكحولي لاوراق القريص على معامل الانقسام الخيطي و التغيرات

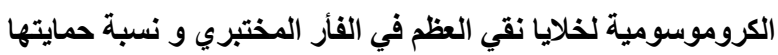

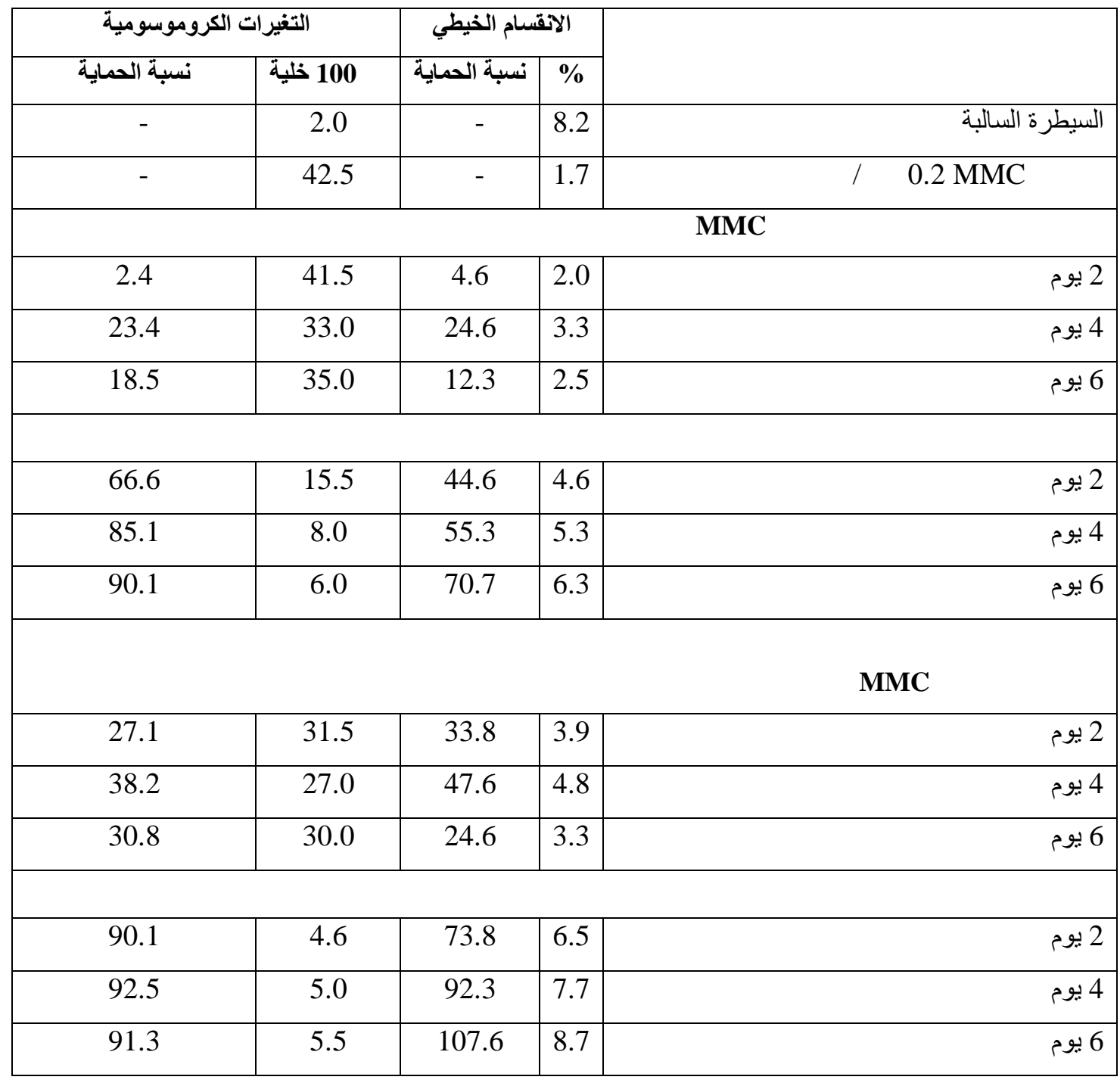




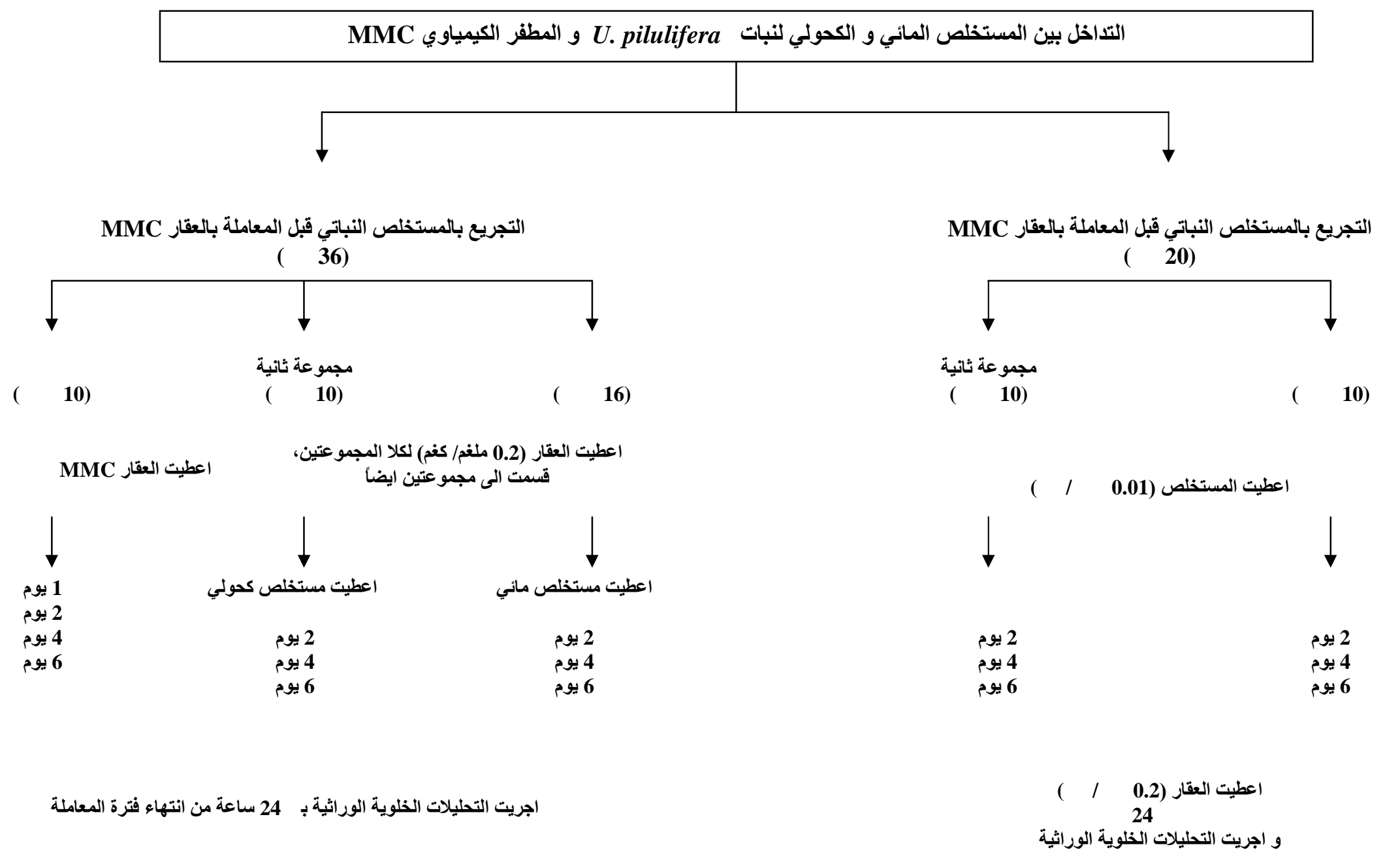

U. pilulifera و المستخلصين الكحولي و المائي لنبات القريص نوع MMC لرعلة الفئران بالعقار 
genotoxic effects of cyclophosphamide in mice by $N$. sativa seeds extracts. Iraqi J. Biotech. 3:21-46.

8. Sakai ; Nagase, H; Ose , Y ; Sato ,T ; Yamada, A; Hibi, M \& Yamada, F(1986) Antimutogenesity of extracts frome crude drugs in Chinese medicine . Mutat.Res, 174:1-4.

9. Harbones, J.B; Mabary, T.J \& Mabary, H( Editor) (1975) physiology and function of flavoroids . Acad. Press New York. PP: 340-341.

10. Shubber EK, Kram D, and Williams JR (1985) In vitro assay of cytogenetic damage induced in bone marrow cells in vivo by chemical carpcinogenes. Japan J. Med. Sci. Biol. 38: 207-216.

11. Littelfield , L ; Colger , S \& Dufrain , $\mathrm{R}$ (1980) Comparison of SCE in human lymphocyte after exposure to MMC in vitro and in vivo . Mutat. Res, 67: 191 195.
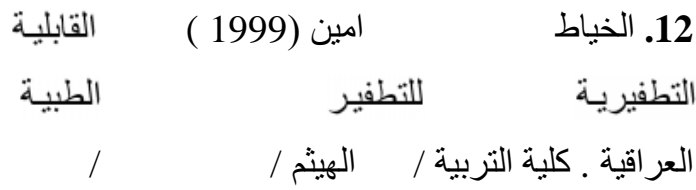

13. Hollander, A (Editor) (1976) Chemical mutagens. Plenum Press. USA.

14. King , M.T; Wild, K; Gorke, E\& Eckhardt , (1982) 5 - Brdurd tablets with improved depot effect for analysis in vivo of SCE in bone marrow and
1. Bassett , M.T ; Hokuninga , E; Mauchaza , B; Levy, L; Ferlay ,J \&Parkin, D.M (1995) Cancer in the African Popultion of Harare , Zimbabwe . Int. J. Cancer, 63:29-36.

2. Al-Khayat BMA, Shubber EK, and Ad'hia AH (2004) Inhibition of the Cytogenetic effects of Hibiscus subdariffa exctract in mouse bone marrow cells and in human lymphocytes cellular. IBN ALHaitham J. for Pure and Applied Sciences. 17: 10-24.

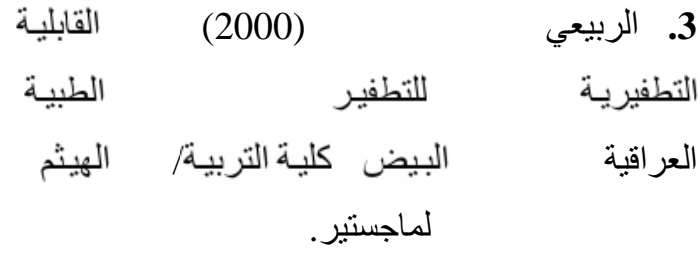

4. AL-Rawi, A (1988) Poisonous Plant of Iraq. Eds. byAL-Rawi, ministry of Agriculture and Irrigation. Baghdad- Iraq. PP: $122-125$.

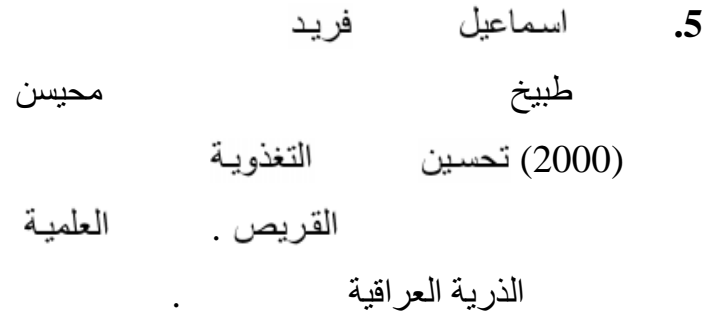

6. Rudd, N.L; Williams, S.E; Evans, M; Hennig, U.G \& Hoar, D.I (1991) Kinetochor analysis of micronuclei allow in sights in to the action of colcemid and mitomycin - C. Mutat.Res , 261:57- 68.

7. Hassan MKA, Shubber EK, and Taj AL-Deen SJ (2004 Cunmmanion of 
Anticarcinogenic Potentials of some Thai Vegetables, Mutat . Res, 402: 247- 258.

18. Deflara, S\& Ramel, C (1988) Mechanisms of Mutagenesis and Carcinogenesis. Classification and Overview; Mutat. Res. 202:285-306.

19. Kuroda, Y; Jain, A.K; Tezuka, H\& Kada. T (1992) Antimutagenecity in cultured mammalian cells. Mutat. Res. 267:

$201-209$. spermatogonic cells . Mutat. Res, 97: 117129.

15. Shubber, E.K \& Juma, A.S (1999) Cytogenetic Effects of herbal medicinal plants U. dioica extracts on mouse somatic cells- Nucleus, 42. 182-187.

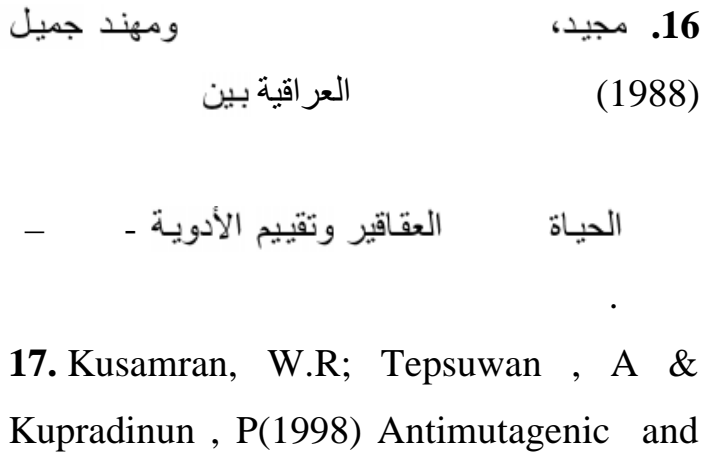

